\title{
Han Chinese festive costumes form of inheritance
}

\author{
Du Bo ${ }^{1, a,{ }^{*}}$, WANG Manqian ${ }^{2, b}$ \\ ${ }^{1}$ School of Fashion, Dalian Polytechnic University, Liaoning 116034,China \\ ${ }^{2}$ School of Fashion, Dalian Polytechnic University, Liaoning 116034,China \\ awww.dubo@163.com, b597077489@qq.com
}

\begin{abstract}
Han Chinese traditional festivals carrying rich historical connotation, is a Chinese rituals has been preserved and most representative cultural heritage. Featured festival apparel goods is an important carrier of people expressing joy, but also reflects the window beautiful country folk culture. Festival clothing worn by people express a festive atmosphere, while inheritance and development of the cultural festival. In moments of national efforts to achieve the great rejuvenation of the nation, to study festive costumes, heritage and carry forward China's cultural festivals is undoubtedly an effective way to enhance the Chinese cultural soft power. By tradition in the form of Han Chinese festive costumes spiritual core research, promote national culture, to enhance the sense of belonging and national pride and unite China forces.
\end{abstract}

Keywords: Natural Imitation, Han Chinese, Clothing Culture festival, Items heritage.

\section{Introduction}

Traditional festivals culture can be inherited from one Generation to another vertically and also spread horizontally. It is an effective approach to express a specific ethnicity, geography, culture and art emotionally. It is a national heritage with great and special status. As we know, garment is a mirror which reflects the folk customs and culture. People express the atmosphere of joy through specific festive costumes, as while continue to heritage and development the festival culture. The research on the inheritance of festive costumes is an effective way to enhance the soft culture power and promote national culture. This will enhance our national sense of belonging and pride, and gather Chinese power.

\section{Organization of the Text learn from natural}

\subsection{Respect the Rules of Nature}

Han festival culture is based on " Respect the rules of nature " . Under the spiritual core of Han nationality, The famous philosopher and great thinker LaoZi elaborated in "Tao Te Ching " Chapter twenty-five chapter, " Human follows land, land follows sky, sky follows Taoism, Taoism follows nature”. This is the natural law for the theoretical point of view of the impact in Chinese culture.

Chinese traditional culture is closely related to the astronomy, calendar, sacrifice, prayer, and all these is based on " the rules of nature " ideological system. Most of Han nationality's festivals are dependent on the development of solar terms, calendar. It is mainly the product of agricultural civilization. For example, the relationship between Spring Festival and spring equinox, the Dragon Boat Festival and the summer solstice, the Mid-Autumn Festival and autumn equinox are all have deep relationship. So we should explore the nature directly, from which to find the form and meaning of the objective word. This is always a visual attraction but also art aesthetics on the guidance and visual psychological needs from the nature.

\subsection{Traditional Festival}

China has been in the self-sufficiency feudal of the agricultural society and the natural economy for A thousand years. And the main traditional festivals are converted from the old season order. People 
pay great attention to the impact of climate on crops. The Chinese traditional festivals are produced according to the lunar calendar, people through the harvest slack when these celebrations, sacrifices the sun and the moon stars, celebrate the bumper harvest, pray for the coming year again and again. In the process of spring, summer, autumn and winter, the complex rules of natural timing were met, and the four seasons and twenty-four solar terms were formed.

Traditional Chinese festivals are various. It is a part of Han's brilliant history and ancient culture. The process of the formation of traditional festivals is the concentrated display of the traditional folk culture vitality. It is the specific humanistic symbol that divides the daily life of the people in the long historical development and social life. It is also the coordination of the time and people. Four seasons as a basis, through the heaven and earth mountains and rivers, sun and moon stars, ascending sacrifice, riding green and other activities to establish heaven and human relations. During the festival, the festival, the ridge, the mountain, the hydrophilic and the folk way of communication with the people, people in the traditional festivals to express the respect for nature, fear of life, harmony between man and nature emotions. "With the world to and from" , "see natural as neighbors, treat the landscape as friends" is the history and culture of long-term accumulation of the process of agglomeration, from the ancient ancestors of the development, from the heritage of the secular folk festivals, clearly record The Chinese nation's rich and colorful social life cultural content.

Chinese festivals are very natural, the ancients considered the natural timing and social humanities timing and made them coordination. As famous historian and writer Liu Yizheng (1880-1956) said:

"The ancients grasp the rules of the nature first, then establish a country " .The ancient Chinese philosophical thought pursues the unity of man and the universe, and the festival is the rhythm of "heaven" and "earth" . It is also the rhythm of "man" and the natural, Chinese festival is the "node" of year, which makes the festival for the ancients and formed a certain degree of sublimation.

\section{Festive Costumes Culture}

\subsection{Festive Costumes}

In October 2003, the 32nd session of the UNESCO adopted the Convention for the Safeguarding of the Intangible Cultural Heritage, which defined the status of social customs, rituals and festivals as intangible cultural heritage. As a form of intangible cultural, the heritage and protection of festivals cultural received a great deal of attention. In 2005,South Korea declare the Jiangling Dragon Boat Festival success intangible world cultural heritage. This greatly stimulate Chinese folklore and festival research .In this moment, a systematic research on Han's traditional festival costumes is an effective way to safeguard our country's festivals cultural.

In China, Han nationality people used to wear more Grand and gorgeous than normal days, and there are a lot of special and meaningful holiday clothing and accessories. Festival culture has breeds the clothing culture, while the clothing culture has enriched the national culture, they two inclusived, influenced and changed. The festive clothing culture research is an effective supplement to our festive culture. As in old China, dress went well with four seasons has become the highlight of the festival. But we are regrettably to see nowadays ,the traditional style ,such as " treasure pots silk flower"in spring festival, “ willow branches” in Ching Ming festival, "multicolored rope” in Dragon Boat Festival All these seems to be memory or even unknown for young people. Too much interesting and popularity festive clothing style are far away from our life, that's the reason many traditional festival lost its original meaning and glory.

\subsection{Han National Costumes}

Han's costumes is one of the oldest national costumes in the world. From humanities ancestry Huaxia, the yellow emperor "dressed well and roled the world” to the Qing government ordered " shaved hair, in Manchu's dress ” , after the world war and With the immersion of Western culture, as well as 
China's modernization process, Han coustumes went far from us. But with the national emphasis on traditional festivals, the traditional crown ceremony, rituals and other traditional etiquette, get more and more people's attention. Han traditional costumes fully embodies the Han nationality of fresh and elegant temperament and refined introverted character. The costumes of Han is not just a clothing system, but also the e believe and the incarnation of the Han national spirit.

China has 56 ethnic groups, different ethnic's festivals and coustumes culture is differ and unic. Unlike some ethnic minorities's festive culture keep in good preservation because of the regional remote. Han's festive culture experienced great influence and hardly can see its Original style. Therefore, its Urgent now make Systematic research on the important culture of the Han's living environment, life production level, aesthetic taste and clothing color, shape, ornaments, Pattern, the relevance of the process of research. From these to explore the Han festival clothing culture in nowadays social status and development prospects.

\section{Inheritance Form}

\subsection{Substance Form of Inheritance}

" substance form of inheritance " concept contains two layers of meaning: both today's ancient civilization of the inheritance, but also to create the era of quality to future generations to be inherited and carry forward.Chinese culture experienced thousands years development, "clothing” language always playing potential function, and with more and more vitality. The pursuit of clothing accessories is directly related to the perfection of the art form and the new, the cultural taste and use of the jewelry is the embodiment of the national soft power.

Dressing specific clothing in festivals is not just interesting, but also meaningful. Actually, for many people especially those who leave their hometown even motherland, once they see these meaningful clothes, will into the festive atmosphere. It is an effective way to explore Chinese festivals costume, and see it as a carrier and a platform to spread the Chinese culture, so that can recall people's memory about their roots. Dress in beautiful festival costumes can also obtain a sense of belonging and national pride. Now what we should do is have depth study of the status festive culture, and through theoretical research and design practice to explore a set of Han festivals with the image of the logo, and also establish and improve the image of our national festivals to play a positive guiding role.

The vitality of traditional festivals is the inheritance and development of human beings. The revitalization of Chinese culture can not by one person, in short term. "substance form of inheritance " is not just inherit the traditional object's style and form , and it is necessary to create high quality festive form in this era. An modern but Rich in culture Festive logo is also an important factor to erect festive atmosphere. As we can see in the Western festivel like Christmas day, Halloween. they both have clear logo image to drive festive atmosphere well. Its urgent to analyzes the current situation of festive culture, and tries to explore the characteristics of the Han Festival festivals through theoretical research and design practice, so that people can get the meaning and interest from our own festivel.

\subsection{The " substance form of inheritance" Design}

The form of "inheritance" is necessary to inherit the traditional culture, but also easy let modern people to accept it. To feed the modern aesthetic and needs, we need to keep traditional festival's essence and erase its dross. But how to define the advantages and disadvantages seems easy, but to expand the concept of modern people, the way to deduce the design, the development of traditional culture and the spirit of today's people are consistent, such a design study Operation has a certain degree of difficulty and challenge. Now we see festive costumes as a material carrier, to explore the "inheritance" way. To follow the ancient's great wisdom " Respect the rules of nature," through the "substance form of inheritance" concept to wake up the young generation of traditional festivals 's attention.

Festival costumes is an important part of festivals and is a form of expression. The dressing style is a demonstration of a strong ideological tradition and ritual rules. 
Inherited the costumes culture need to study the relationship among the shape, color, quality and inner culture of the Han nationality festivals. And is also necessary to consider the traditional solar terms and calendars in China. Above all these to proves the spiritual core of the Han nationality festival.

To sum up the form of traditional festive costumes, analyze Its essence and go on with the modern design research and develop the festival costumes. For example. "the design of the new Chinese wedding dress", "the Chinese New Year Chinese children's clothing design”, "the Dragon Boat Festival accessories design”, "festive tourism jewelry design” or "Han festival logo clothing design" these modern style festival costume's research and development, trying merge tradition culture with fashion to get the national identity.

From 2010, the Ministry of Culture, the National Tourism Administration launched a Chinese cultural tourism theme year every four years. In addition, every two years will hold a session of Chinese International Cultural Tourism Festival, and every two years will announced 8 to 10 local cultural tourism festivals into the support directory. " The twelfth Five-Year period national cultural reform and development plan" clearly pointed out that "to expand the use of intangible cultural heritage." All these stimulate plan encouraged local governments vigorously develop the intangible cultural heritage protection, inheritance and development of related industries. In-depth Dig the cultural connotation of the national traditional festivals, and build the brand of native cultural festivals. Reference our own national culture With other countries, the formation of different cultures of multi-angle understanding can help us know more about our own culture. And its an Effective way to strengthen the two-way communication of different cultures, to achieve multi-cultural harmony and common development. The approach how Western festival been accept by different culture all around the world is also need to prep .The western festival's modern communication ideas, the operation method of inheritance and innovation of local traditional festivals is also worthy our Chinese to learn and reference.

Creative design needs not just simply copy but to inherited the spirit of traditional humanistic thought. To Keep pace with the times, its important to focused on the things around and observe carefully. Through Improvement and adjustment, our festival costumes design can adapt to this modern and abundant cultural life. With the increasing demand for spiritual and cultural life, festivals culture and its related activities and accessories get high attention because its close to the lives of residents, and get highest degree of participation in cultural expressions. Especially the festival accessories can produce a huge economic, cultural and social value, in a short period of time.

Its an necessary and useful method to promote fashionable and cultural national festival costumes design with modern communication means, so that more people can get the meaning of festive costumes and feel the joy of festivals. In this case, people inheritance and carry forward the national festivals cultural, get the national sense of belonging and cultural self-confidence. No matter which nation or culture, inheritance is undoubtedly the most important. Heritage is not take it and use it , but to meet the current fashion taste, accepted by people, and even been loved by this period.

\section{Conclusions}

The research on the form of festive costumes has a strong impetus to the market research and development of festival clothing design.

The inheritance of culture is a monastery process that requires certain circumstances and conditions. Therefore, to inherit and carry forward our excellent traditional festivals culture, the first is to create the environment and conditions. To awaken the public, especially the young generation of traditional culture of consciousness. "Cultural consciousness" is to fully understand the tradition and reality, to achieve the transmission of traditional festivals, but also through the introduction of excellent Western festivals for the traditional festive culture into the new blood and nutrition, so that the traditional festive culture full of vitality. Through the adjustment of design, the traditional image of 
festival can be fashion, as modern people can accept. The series of festival theme costume research design will be a booster to help the development of festivals cultural market and creative industries into vitality.

\section{Acknowledgments}

This work was financially supported by The Ministry of Education, Humanities and Social Sciences Research Youth Fund Project 《Based on the nature of the spiritual core, Study on Han Chinese festival costumes culture form of inheritance》 [Project approval number: 15YJC760022] .

\section{References}

[1]Huamei,costumes and festivals, China Times Economic Publishing House, 2010

[2]R. Turner Wilcox ,Folk and Festival Costume, Dover Publications, 2011

[3]Huang Nengfu, Chen Juanjuan, Chinese clothing history, 2014

[4]Wang Xi ,Ming Dynasty clothing research, China Bookstore, 2013.8

[5]Zhang Hao,Chinese clothing aesthetic, Tianjin University Press, 2013.8

[6]Lin Rao (Taiwan), experience marketing elements combined with cultural and creative industries -2012 Miaoli County Sanyi Yunhuolong Festival, Ocean Leisure Management Journal, 2013.4

[7]Garth L. Green, Philip W. Scher,Trinidad Carnival: The Cultural Politics of a Transnational Festival, Indiana University press, 2007.

[8] Chinese Art Anthropology Society, Inner Mongolia University Art Institute,Intangible cultural heritage and art anthropology research school publishing house, 2013 